\title{
Effect of Intercropping of Sesbania rostrata with Transplant Aman Rice on Yield and Profitability
}

\author{
M. M. Rana ${ }^{1}$, M. S. U. Bhuiya ${ }^{2}$, M. I. M. Akhand ${ }^{1}$ \\ ${ }^{1}$ Scientific officer, Agronomy Division, Bangladesh Rice Research Institute, Gazipur-1701 \\ ${ }^{2}$ Professor, Dept. of Agronomy, Bangladesh Agricultural University, Mymensingh-2202
}

\begin{abstract}
The effect of intercropping of Sesbania rostrata with Transplant Aman rice on yield and profitability was determined at the Agronomy Field Laboratory, Bangladesh Agricultural University, Mymensingh, from July to December 2009. The experiment consisted of five treatments viz.; i) intercropping Sesbania in between two rows of rice, ii) intercropping Sesbania in two rows interval of rice, iii) intercropping Sesbania around the rice field, iv) sole rice and $v$ ) sole Sesbania rostrata. The results revealed that rice grain yield decreased to a significant level by Sebania intercropping compared to sole rice which varied from 11.43 to $28.21 \%$, with the maximum (28.21\%) by intercropping Sesbania in between two rows of rice followed by intercropping Sesbania in two rows interval of rice (12.5\%) against the minimum (11.43\%) by intercropping Sesbania around the rice field. In terms of total rice grain yield equivalent (TRGYE), the highest TRGYE (6.88 ton $\mathrm{ha}^{-1}$ ) was recorded for the treatment of intercropping Sesbania in two rows interval of rice followed by intercropping Sesbania in between two rows of rice $\left(6.00\right.$ ton ha $\left.\mathrm{h}^{-1}\right)$ and intercropping Sesbania around the rice field (5.87 ton $\left.\mathrm{ha}^{-1}\right)$ against the minimum (5.60 ton $\left.\mathrm{ha}^{-1}\right)$ for sole rice clearly indicating yield advantages of intercropping over monocropping of rice. Similarly the net field benefits obtained from different intercropping systems were considerably higher than the sole cropping of rice. The maximum net benefit of $T \mathrm{Tk} .73531 \mathrm{ha}^{-1}$ was recorded for intercropping Sesbania in two rows interval of rice which is $26.68 \%$ more than sole rice (Tk. $59620 \mathrm{ha}^{-1}$ ).
\end{abstract}

Key words: Intercropping, Rice equivalent yield, LER

\section{Introduction}

Rice (Oryza sativa L.) is the stable food crop for more than half of the world's population. In Asia alone, more than 2 million people obtain 60 to 70 percent of their calorie intake from rice and its derived products (FAO, 2003). Rice is grown in 10.417 million hectares of land with a production of 28.91 million tons (BBS, 2009). Among the three distinct seasons aman rice covers the largest area of 5.05 million hectares with a production of 9.662 million tons of rice (BBS, 2009).

Sesbania rostrata is a unique species belonging to the family Leguminosae and sub family Papilionaceae. It is an annual species having nitrogen fixing roots. It is a newly introduced species in Bangladesh can be propagated through seedlings and cuttings even in water logged condition.

Intercropping is one of the important techniques to intensify production by growing simultaneously two or more crops in the same piece of land. The growing of two or more crops simultaneously in the same piece of land in alternate rows or set of rows is called intercropping (Zandstra, 1979).

The agricultural land of Bangladesh is being reduced by about $1 \%$ per annum (Hussain et. al., 2006) while population is increasing at an alarming rate of $1.43 \%$ (Economic Review, 2006). Farmers are under continuous pressure for producing for more and more from reduced land. Drastic increase in world population has increased the demand for food to an unprecedented level and the present system of sole cropping has failed to meet the diversified domestic needs of small farmers from the dwindling supply of new lands for cultivation and other limited resources. These conditions necessitates a shift from mono/sole cropping to multiple cropping (intercropping), which is being considered to be an excellent strategy for intensifying land use, absorbing excess labour and increasing income and production per unit area and time both in the irrigated and rainfed areas. Intercropping being a unique cropping system offers the possibility of yield advantage relative to sole cropping through yield stability and improved yield (Willey, 1979).

For growing Sesbania rostrata as green manuring crop, seed production is a limiting factor. Seed production of Sesbania is a problem to the farmers of Bangladesh, because it requires much time in the field as a sole crop to produce seeds for which the farmers have to sacrifice a main crop. Intercropping of $S$. rostrata with transplant aman rice may have the advantage of getting both seeds as well as biomass within a short period of 3 to 4 months without disturbing transplant aman rice. For seed production cuttings may be used. It may be planted even in the months of July-August in low-lying areas. This may help to get quality seed. Poor germination of Sesbania rostrata has been reported from farmers' field and research stations. Seeds obtained from cuttings and clipped plants may produce quality seeds and can 
enhance the germination. S. rostrata is a short day plant and it produces seeds during the months of November-December when transplant aman rice is harvested. Therefore, this species can be easily intercropped with transplant aman rice to get biomass and quality seeds. The present study was conducted with the objectives to develop sustainable and economically viable intercropping system of Sesbania rostrata with transplant aman rice and seed production of Sesbania rostrata through intercropping with transplant aman rice.

\title{
II. Materials And Methods
}

The experiment was conducted at the Agronomy Field Laboratory, Bangladesh Agricultulal University, Mymensingh, during the period from July to December 2009 to evaluate the effect of intercropping of Sesbania rostrata with transplant aman rice cv. BR11 (Mukta) on its yield and profitability. Soil of the experimental field was more or less neutral with a $\mathrm{pH}$ value of 6.7, low in organic matter and fertility level. The land type was medium high with silty loam texture. The experiment consisted of five treatments viz.; i) intercropping Sesbania in between two rows of rice, ii) intercropping Sesbania in two rows interval of rice, iii) intercropping Sesbania around the rice field, iv) sole rice and v) sole Sesbania rostrata. The experiment was laid out in a randomized complete block design with three replications. Layout of the experiment was done on 20 July 2009 with inter plot spacing of $1.0 \mathrm{~m}$ and inter block spacing of $1.0 \mathrm{~m}$. The size of each unit plot was $4.0 \mathrm{~m} \times 2.5 \mathrm{~m}$. The seedling of rice variety BR11 (Mukta) and Sesbania rostrata $(80 \mathrm{~cm}$ top cutting) were used as plant materials. Thirty five day old seedlings of rice were transplanted on 22 July 2009 in assigned plots at $20 \mathrm{~cm} \times 15 \mathrm{~cm}$ spacing. The Sesbania top cuttings $(80 \mathrm{~cm})$ were planted in the respective plots according to lay out on 28 July 2009 at a plant to plant distance of $50 \mathrm{~cm}$ after 7 days of transplanting of rice seedlings. Fertilizers were applied in all rice sole and intercropped plots at the rates of 200, 120, 70, 60 and $10 \mathrm{~kg} \mathrm{ha}^{-1}$ of Urea, TSP, MoP, Gypsum and $\mathrm{ZnSo}_{4}$, respectively. Except urea, all other fertilizers were applied in the experimental plots uniformly before final land preparation and urea was top dressed in three equal splits on 15, 55 and 55 days after transplanting of rice. No fertilizer was applied in the plots where Sesbania was grown as sole crop. Weeding and other intercultural operations were done as when required. Maturity of rice and Sesbania occurred at different times. Harvesting of Sesbania was done between 20 October to 10 November 2009 depending upon the maturity of plants. The rice was harvested at full maturity on 19 November 2009. The harvested Sesbania and rice were then dried, threshed and cleaned and necessary data were collected. The collected data were compiled and tabulated for statistical analysis. Analysis of variance was done with the help of computer package, M-Stat C. The mean differences among the treatments were adjudged as per Duncan's Multiple Range Test (Gomez and Gomez, 1984).

\begin{abstract}
III. Results And Discussion
Grain yield and Straw yield of rice

Grain yield of aman rice progressively decreased due to intercropping treatments compared to its sole crop. The highest grain yield $\left(5.60 \mathrm{tha}^{-1}\right)$ obtained from the sole of rice and lowest $\left(4.02 \mathrm{tha}^{-1}\right)$ was at intercropping Sesbania in between two rows of rice (Table 1). The probable reasons for reduction of rice grain yields might be due the shading effects of closer planting of Sesbania and for the competition for light, space, moisture and nutrient with rice. Reduction in grain yield of rice due to intercropping was also reported by Chandra et al., (1992), Saeed et al., (1999) and Joshi (2002).

The yield of straw varied significantly due to intercropping of Sesbania with transplant aman rice (Table 1). The highest straw yield $\left(7.40 \mathrm{t} \mathrm{ha}^{-1}\right)$ was obtained from sole of rice where no shading effect was existed and lowest $\left(5.50 \mathrm{t} \mathrm{ha}^{-1}\right)$ was at planting of Sesbania in between two rows of rice. Shading of Sesbania plant resulted less number of total tillers hill ${ }^{-1}$ resulted low straw yield. The obtained result is in conformity with the findings of Biswas et al. (1991) and Alam (1995).
\end{abstract}

\section{Seed yield and Stick yield of Sesbania rostrata}

Seed yield and stick yield varied significantly due to different types of spacing arrangements of Sesbania intercropping with rice. From Table 1, it is revealed that sole crop of Sesbania treatment produced highest seed yield $\left(971.25 \mathrm{~kg} \mathrm{ha}^{-1}\right)$ and lower from $\left(418.00 \mathrm{~kg} \mathrm{ha}^{-1}\right)$ intercropping Sesbania around the rice field. The adverse effect on yield of the crop due to intercropping occurred mainly due to competition among companion crops for light, space, nutrients and water etc. the more number of plant population was grown, the more competition for light, space, nutrient, humidity and moisture etc. increased and thus yield differences occur. Highest stick yield (1091.36 $\mathrm{kg} \mathrm{ha}^{-1}$ ) was recorded from growing Sesbania as sole and lowest $\left(524.95 \mathrm{~kg} \mathrm{ha}^{-1}\right)$ when Sesbania was intercropped around the rice field (Table 1). The probable causes for getting higher Stick yield might be due to more vigorus growth and higher branching of Sesbania at sole spacing. 
Effect of Intercropping of Sesbania rostrata with Transplant Aman Rice on Yield and Profitability

Table1: Grain, straw yield of rice and Seed, stick yield of Sesbania rostrata

\begin{tabular}{|l|c|c|c|c|}
\hline \multirow{2}{*}{ Treatments combinations } & \multicolumn{4}{|c|}{ Yield } \\
\cline { 2 - 5 } & \multicolumn{2}{|c|}{ Rice $\left(\mathrm{t} \mathrm{ha}^{-1}\right)$} & \multicolumn{2}{c|}{ Sesbania $\left(\mathrm{kg} \mathrm{ha}^{-1}\right)$} \\
\cline { 2 - 5 } & Grain & Straw & Seed & Stick \\
\hline $\begin{array}{l}\text { Intercropping Sesbania } \text { in between } \\
\text { two rows of rice }\end{array}$ & $4.02 \mathrm{~b}$ & $5.50 \mathrm{c}$ & $667.59 \mathrm{~b}$ & $784.31 \mathrm{~b}$ \\
\hline $\begin{array}{l}\text { Intercropping Sesbania in two rows } \\
\text { interval of rice }\end{array}$ & $4.90 \mathrm{~b}$ & $6.55 \mathrm{~b}$ & $648.59 \mathrm{~b}$ & $748.64 \mathrm{~b}$ \\
\hline $\begin{array}{l}\text { Intercropping Sesbania around the } \\
\text { rice field }\end{array}$ & $4.96 \mathrm{~b}$ & $6.32 \mathrm{~b}$ & $418.00 \mathrm{c}$ & $524.95 \mathrm{c}$ \\
\hline Sole rice & $5.60 \mathrm{a}$ & $7.40 \mathrm{a}$ & - & - \\
\hline Sole Sesbania & - & - & $971.25 \mathrm{a}$ & $1091.36 \mathrm{a}$ \\
\hline $\mathrm{S} \overline{\mathrm{X}}$ & 0.17 & 0.21 & 37.68 & 41.93 \\
\hline $\mathrm{CV}(\%)$ & 12.12 & 11.07 & 12.36 & 10.42 \\
\hline Level of significance & $* *$ & $* *$ & $* *$ & $* *$ \\
\hline
\end{tabular}

** = Significant at $1 \%$ level of probability

In a column figures with same letter or without letter do not differ significantly whereas figures with dissimilar letter differ significantly (as per DMRT)

\section{Rice equivalent yield $\left(\mathrm{th} \mathrm{h}^{-1}\right)$}

Rice equivalent yield was found to be higher ( $4 \%$ to $22 \%$ ) compared to sole crop in all the treatment combinations of rice with Sesbania intercropping. Grain yield of sole rice was $5.60 \mathrm{t} \mathrm{ha}^{-1}$ and seed yield of sole Sesbania was $971.25 \mathrm{~kg} \mathrm{ha}^{-1}$. The treatment intercropping Sesbania in two rows interval of rice produced highest $\left(6.88 \mathrm{tha}^{-1}\right)$ rice equivalent yield followed by intercropping Sesbania in between two rows of rice (6.00 ton ha-1) and intercropping Sesbania around the rice field $\left(5.87 \mathrm{t} \mathrm{ha}^{-1}\right)$ against the minimum $\left(5.60 \mathrm{t} \mathrm{ha}^{-}\right.$ ${ }^{1}$ ) for monocropped rice. The highest rice equivalent yield is due to production of more seed yield of Sesbnania rostrata. Increase in TRGYE as a result of intercropping was also reported by Banik \& Bagchi (1994) and Qayyum \& Muniruzzaman (1995).

\section{Land equivalent ratio (LER)}

Land equivalent ratio indicates the ratio of land required by pure stand crop to produce the same yield as that of intercrop. Thus it refers to the relative area of pure crop or crops required to produce the same yield or yields as achieved in intercropping of the same crops (Willey, 1979). The land equivalent ratio was computed on the land area basis only and the duration of the companion crops were not taken into consideration. Land equivalent ratio varied from 1.26 to 1.59 due to intercropping of Sesbania with transplant aman rice. The highest land equivalent ratio (1.59) was observed in the treatment of intercropping Sesbania rostrata top cutting in two rows interval of rice. This might be due to the contribution by both the rice and Sesbania relative yields which were higher at that spacing. Singh et al. (2002) also observed similar findings in their experiment.

Table2. Yield of rice and Sesbania as a sole and intercropping and land equivalent ratio

\begin{tabular}{|c|c|c|c|c|c|c|c|c|c|}
\hline \multirow[b]{3}{*}{ Treatments combinations } & \multicolumn{4}{|c|}{ Yield } & \multirow{3}{*}{$\begin{array}{l}\% \text { Rice } \\
\text { grain } \\
\text { yield } \\
\text { reduction }\end{array}$} & \multicolumn{2}{|c|}{ Relative yield (\%) } & \multirow{3}{*}{$\begin{array}{l}\text { Land } \\
\text { equival } \\
\text { ent ratio } \\
\text { (LER) }\end{array}$} & \multirow{3}{*}{$\begin{array}{c}\text { Rice } \\
\text { equivalent } \\
\text { yield* (t ha' } \\
\text { 1) }\end{array}$} \\
\hline & \multicolumn{2}{|c|}{ Rice $\left(\mathrm{t} \mathrm{ha}^{-1}\right)$} & \multicolumn{2}{|c|}{ Sesbania $\left(\mathrm{kg} \mathrm{ha}^{-1}\right)$} & & \multirow[t]{2}{*}{ Rice } & \multirow[t]{2}{*}{ Sesbania } & & \\
\hline & Grain & Straw & Seed & Stick & & & & & \\
\hline $\begin{array}{l}\text { Intercropping Sesbania in } \\
\text { between two rows of rice }\end{array}$ & 4.08 & 5.75 & 691.92 & 802.93 & 28.21 & 0.728 & 0.712 & 1.44 & $6.00(107 \%)$ \\
\hline $\begin{array}{l}\text { Intercropping Sesbania in two } \\
\text { rows interval of rice }\end{array}$ & 5.00 & 6.20 & 677.18 & 750.91 & 12.5 & 0.893 & 0.697 & 1.59 & $6.88(122 \%)$ \\
\hline $\begin{array}{l}\text { Intercropping Sesbania around } \\
\text { the rice field }\end{array}$ & 4.75 & 6.58 & 404.70 & 542.79 & 11.43 & 0.848 & 0.416 & 1.26 & $5.87(104 \%)$ \\
\hline Sole rice & 5.60 & 7.40 & - & - & - & 1 & - & 1 & $5.60(100 \%)$ \\
\hline Sole Sesbania & - & - & 971.25 & 1091.36 & - & - & - & - & - \\
\hline
\end{tabular}

Price: Rice grain $=$ Tk. $18 \mathrm{~kg}^{-1}$, Sésbania seed $=$ Tk. $50 \mathrm{~kg}^{-1}$

* Rice equivalent yield increase or decrease (\%) 


\section{Total variable cost}

The total variable cost of intercropping of transplant aman rice with Sesbania rostrata, under different spacing arrangements and length of top cutting has been studied and presented in Table 3. Cost of seeds, fertilizer, labour, pesticide etc. were calculated for total variable cost. Fertilizer cost and labour number were similar for the all treatments of rice but the number of labourers varied in planting of cuttings with different spacings. Pesticidal cost was also same for all the treatments. The lowest total variable cost (Tk. 55,980 ha ${ }^{-1}$ ) was found from the rice sole treatment which is due to requirement of less number of labourer to manage the rice crop only. The highest total variable cost $\left(\mathrm{Tk} .65,980 \mathrm{ha}^{-1}\right)$ was observed in the treatment intercropping Sesbania in between two rows of rice. The highest variable cost is due to requirement of more number of labours $\left(50 \mathrm{No} \mathrm{ha}^{-1}\right)$ to plant the Sesbania top cutting in between two rows of rice.

\section{Gross and net returns}

A gross and net return provides an economic assessment of intercropping in terms of increased value per unit area of land. Gross return of grain and straw of rice and seed and stick yields of Sesbania have been shown in Table 4. The highest gross return (Tk. $138511 \mathrm{ha}^{-1}$ ) was obtained from the treatment intercropping Sesbani in two rows interval of rice; where the lowest gross return (Tk. $115600 \mathrm{ha}^{-1}$ ) was obtained from rice sole rice. Intercropping Sesbania top cutting in two rows interval of rice resulted highest gross return and this is due to more grain and straw yield of rice and seed and stick yield of Sesbania rostrata. The net return of intercropping of rice with Sesbania at different spacings also showed the similar trend as exhibited by total gross return (Table4).The result of the present study is in partial conformity with the findings of Prajitno (2001) and Dhimmar (2003) where they obtained higher net return in rice based intercropping systems with different crops.

\section{Benefit cost ratio}

The benefit cost ratio varied from 1.85 to 2.13 due to intercropping of Sesbania with transplant aman rice. The highest benefit cost ratio (2.13) was obtained from the treatment intercropping Sesbania in two rows interval of rice (Table 4) against the minimum (1.85) by intercropping Sesbania in between two rows of rice. The maximum benefit cost ratio in this treatment might be due to high yield, high land equivalent ratio (LER) and high market price of the crops.

\section{Conclusion}

From the above results and discussion it can be stated that within the five treatments, intercropping Sesbania in two rows interval of rice was better, because this treatment resulted higher rice equivalent yield, gross return, net return and benefit cost ratio. From the result it can be concluded that the treatment intercropping Sesbania rostrata top cutting in two rows interval of rice is suitable for its economic advantage and Sesbania rostrata can be easily intercropped with transplant aman rice for getting extra economic benefits. However, further studies are required to arrive a definite conclusion at different agro-ecological zones of Bangladesh

Table3. Total variable cost of intercropping of Sesbania rostrata with transplant aman rice

\begin{tabular}{|c|c|c|c|c|c|c|c|}
\hline Treatments combinations & $\begin{array}{c}\text { Land } \\
\text { Preparation } \\
(\text { Tk. ha-1) }\end{array}$ & $\begin{array}{c}\text { Cost of } \\
\text { fertilizers } \\
\left(T k \text { ha }^{-1}\right)^{*}\end{array}$ & $\begin{array}{l}\text { Labour } \\
\text { for sole } \\
\text { rice ha: } \\
{ }^{1} \text { (No.) }\end{array}$ & $\begin{array}{l}\text { Labour for } \\
\text { Sesbania } \\
\text { intercrops } \\
\text { ha }^{-1} \text { (No.) }\end{array}$ & $\begin{array}{l}\text { Wages of } \\
\text { labour } \\
\left(T k \text { day }^{-1}\right)\end{array}$ & $\begin{array}{c}\text { Pesticide } \\
\text { cost (Tk. } \\
\text { ha-1) }^{-1} \text {. }\end{array}$ & $\begin{array}{l}\text { Total variable cost** } \\
\left.\text { (Tk. ha }{ }^{-1}\right)\end{array}$ \\
\hline & 1 & 2 & 3 & 4 & 5 & 6 & $7=\{1+2+(3+4) \times 5+6\}$ \\
\hline $\begin{array}{l}\text { Intercropping Sesbania in } \\
\text { between two rows of rice }\end{array}$ & 4000 & 10730 & 200 & 50 & 200 & 1250 & 65980 \\
\hline $\begin{array}{l}\text { Intercropping Sesbania in } \\
\text { two rows interval of rice }\end{array}$ & 4000 & 10730 & 200 & 45 & 200 & 1250 & 64980 \\
\hline $\begin{array}{l}\text { Intercropping Sesbania } \\
\text { around the rice field }\end{array}$ & 4000 & 10730 & 200 & 35 & 200 & 1250 & 62980 \\
\hline Sole rice & 4000 & 10730 & 200 & 0 & 200 & 1250 & 55980 \\
\hline Sole Sesbania & 2000 & - & - & 50 & 200 & - & 12000 \\
\hline
\end{tabular}

*Urea-200 kg@ Tk. $12 \mathrm{~kg}^{-1}$,TSP-120 kg@ Tk. 35 kg-1, MoP -70 kg @ Tk. $35 \mathrm{~kg}^{-1}$, Gypsum-60 kg @ Tk. 8 $\mathrm{kg}^{-1}, \mathrm{ZnSO}_{4}-10 \mathrm{~kg} @ \mathrm{Tk} .120 \mathrm{~kg}^{-1}$, Basudin-5 kg @ Tk. $150 \mathrm{~kg}^{-1}$, Sumithion-Tk $500 \mathrm{ha}^{-1}$. ** Costs of seeds of rice and Sesbania were not included. 
Table4. Economic analysis (Cost and return) of intercropping of Sesbania rostrata with transplant aman rice cv. BR11

\begin{tabular}{|c|c|c|c|c|c|c|c|c|c|c|}
\hline \multirow[t]{3}{*}{ Treatments combinations } & \multirow{2}{*}{$\begin{array}{c}\text { Total } \\
\text { variabl } \\
\text { e cost } \\
(\mathrm{Tk} . \\
\left.\mathrm{ha}^{-1}\right)\end{array}$} & \multicolumn{2}{|c|}{$\begin{array}{l}\text { Rice yield } \\
\left(\mathrm{t} \mathrm{ha}^{-1}\right)\end{array}$} & \multicolumn{2}{|c|}{$\begin{array}{l}\text { Sesbania yield } \\
\left(\mathrm{Kg} \mathrm{ha}^{-1}\right)\end{array}$} & \multicolumn{3}{|c|}{$\begin{array}{c}\text { Gross return** } \\
\left(\mathrm{Tk} . \mathrm{ha}^{-1}\right)\end{array}$} & \multirow{2}{*}{$\begin{array}{c}\text { Net } \\
\text { return } \\
(\mathrm{Tk} . \mathrm{ha}- \\
\text { l) }\end{array}$} & \multirow{2}{*}{$\begin{array}{c}\text { Benefit } \\
\text { cost } \\
\text { ratio } \\
(\mathrm{Tk} / \mathrm{Tk})\end{array}$} \\
\hline & & $\begin{array}{l}\text { Grain } \\
\text { (a) }\end{array}$ & $\begin{array}{l}\text { Straw } \\
\text { (b) }\end{array}$ & $\begin{array}{l}\text { Seed } \\
\text { (c) }\end{array}$ & $\begin{array}{l}\text { Stick } \\
\text { (d) }\end{array}$ & $\begin{array}{l}\text { Rice } \\
(a+b)\end{array}$ & $\begin{array}{c}\text { Sesban } \\
\text { ia } \\
(\mathrm{c}+\mathrm{d})\end{array}$ & Total & & \\
\hline & 1 & & & & & 2 & 3 & $4=2+3$ & $5=4-1$ & $6=4 \div 1$ \\
\hline $\begin{array}{l}\text { Intercropping Sesbania in } \\
\text { between two rows of rice }\end{array}$ & 65980 & 4.08 & 5.75 & 691.92 & 802.93 & 84940 & 37004 & 121944 & 55964 & 1.85 \\
\hline $\begin{array}{l}\text { Intercropping Sesbania in } \\
\text { two rows interval of rice }\end{array}$ & 64980 & 5.00 & 6.20 & 677.18 & 750.91 & 102400 & 36111 & 138511 & 73531 & 2.13 \\
\hline $\begin{array}{l}\text { Intercropping Sesbania } \\
\text { around the rice field }\end{array}$ & 62980 & 4.75 & 6.58 & 404.70 & 542.79 & 98660 & 21863 & 120523 & 57543 & 1.91 \\
\hline Sole rice & 55980 & 4.60 & 7.40 & - & - & 115600 & - & 115600 & 59620 & 2.06 \\
\hline Sole Sesbania & 12000 & - & - & 971.25 & 1091.36 & - & - & - & - & - \\
\hline
\end{tabular}

**Rice: Rice grain @ Tk. $18 \mathrm{~kg}^{-1}$, Straw @ Tk. $2 \mathrm{~kg}^{-1}$, Sesbania: Seed @ Tk. $50 \mathrm{~kg}^{-1}$, Stick @ Tk. $3 \mathrm{~kg}^{-1}$.

\section{References}

[1] Alam, M. S. 1995. Effect of intercropping arrangements of Sesbania rostrata in transplant aman rice. An M.S. thesis. Dept. Agron. Bangladesh Agril. Univ. Mymensingh.pp.1-40.

[2] Banik, P. and D.K. Bagchi. 1994. Evaluation of rice (Oryza sativa) and legume intercropping in Bihar plateau. Indian J. Agric Sci., 64: 364-368.

[3] BBS (Bangladesh Bureau of Statistics). 2009. Statistical Year Book of Bangladesh. Stat. Div., Minst. Planning, Bangladesh Bur. Stat., Govt. People's Repub. Bangladesh, Dhaka, pp. 123.

[4] Bhuiya, M. S. U., Islam, N. Das, T. K. and Hossain S. M. A. 1993. Effect of intercropping of Sesbania rostrata on the growth and yield of rice. Bangladesh J. Agril. Sci. 20(2):285-290.

[5] Biswas, J. C., Roy, B. C. and Siddique, S. B. 1991. Establishing green manuring crops with irrigated boro rice. Annals of Bangladesh Agric. 1(2):113-115.

[6] Chandra, D., Raju A. R. and Singh, U. D. 1992. Evaluation of suitable rice and pigeon pea varieties for intercropping under upland conditions. Int. Rice Res. Newsl. (IRRN), pp.17:19.

[7] Dhimmar, S. K. 2003. Effect on growth and yield of rabi caster in pulses intercropping under varying planting geometry. American J. Sci. Res. 4: 165-168

[8] Economic Review of Bangladesh. 2006. Economic advisory subdivision, Economic Divi. , Ministry of planning, Govt. The People's Repub. of Bangladesh, Dhaka, p. 130.

[9] FAO (Food and Agriculture Organization). 1988. Land Resources Appraisal of Organization for Agricultural Development. Report 2. Agro-Ecological Regions of Bangladesh. pp. 212-221.

[10] Gomez, K. A. and Gomez, A. A. 1984. Duncan's Multiple Range Test. Statistical Procedures for Agril. Res. ${ }^{\text {nd }}$ Edn., A Wiley Inter. Science Publication, John and Sons, New York. pp. 202-215.

[11] Hussain, M. M. , Alam, M.S., Islam, M. A., Rashid, M. M., Islam, M. F., Rashid, M. A., Razzak, M. A., Momin, M. S. I., Islam, M. R., Kabir, H., Parvin, ,S and Mukul, H. R. 2006. Three years experiences with drum seeder for direct wet seedling of rice in Bangladesh. In: Baque, M. A(eds.). Proceeding of Twenty First BRRI-DAE joint workshop, 19-21 September, 2006, BRRI, Joydebpur, pp 1-13.

[12] Joshi, M. 2002. Dynamics of rice-based cropping systems in Southern transitional zone of Karnatka,India. Int. Rice Res. Newsletter, 27(1): 41-42.

[13] Prajitno, D. 2001. Studies on the interaction between upland rice and other crops in intercropping system. JIFS. 4: 1-10.

[14] Qayyum, M. A. and Muniruzzaman, A. F. M. 1995. Intercropping maize (Zea mays) and rice (Oryza sativa) with Balck gram (Phaseolus mungo). Indian J. Agron., 40: 20-25.

[15] Saeed. M., A. Ullah, R. Ahmad and A. Jabbar. 1999. Bio-economic assessment of direct seeded rice-based intercropping systems under strip plantation. Pak. J. Biol. Sci., 2(3): 980-983

[16] Singh, G., Singh, O. P., Kumar, M., Rajput, A. L. and Maurya, S. 2002. Effect of intercrops on yield and economics, weeds and pest infestation of deep water rice. Ann. Agric. Res. 17(1): 14-17.

[17] Willey, R. W. 1979. Intercropping- its importance and research needs. 1. Competition and yield advantage, and 2. Agronomy and research approaches. Field Crop Absts. 32-1-10, 73-85.

[18] Willey, R. W. 1979. Intercropping- its importance and research needs. Part-1. Competition and yield advantages. Field Crop Absts. 32(1):1-10.

[19] Zandstra, H. G. 1979. Terminologies in cropping systems "Definitions and Parameters"- Lecture notes of six month cropping systems training programme at IRRI, Philippines. 